\title{
Cyanobacteria Diversity in Blooms from the Greater Sudbury Area
}

\author{
Suzanne Evans, Mazen Saleh* \\ Department of Biology, Laurentian University, Sudbury, Canada \\ Email: * msaleh@laurentian.ca
}

Received 22 May 2015; accepted 19 July 2015; published 22 July 2015

Copyright (C) 2015 by authors and Scientific Research Publishing Inc.

This work is licensed under the Creative Commons Attribution International License (CC BY). http://creativecommons.org/licenses/by/4.0/

(c) (i) Open Access

\begin{abstract}
The Greater Sudbury Area is approximately $400 \mathrm{~km}$ north of the city of Toronto and falls within a large number of temperate lakes of various sizes. This area has been mined for nickel and other metals for several decades. These activities have affected the watersheds of Northern Ontario and have influenced the chemistry of a number of lakes. Blooms of cyanobacteria occur yearly in several lakes, mainly in the early and late summer months. Much of the chemistry of these lakes is known but the nature of the cyanobacterial blooms and the factors that may contribute to their sudden appearance are not. We sampled blooms from five Greater Sudbury Area lakes and identified the species present by morphological and molecular methods. The dominant genera present as characterized by morphological examination were Synechocystis, Leptolyngbya, Anabaena, Cylindrospermum, Nostoc, Borzia, Phormidium, Pseudoanabaena, Oscillatoria, and Planktothrix. Three of these isolates, Leptolyngbya, Anabaena, and Planktothrix were confirmed by partial rRNA sequence analysis.
\end{abstract}

\section{Keywords}

Cyanobacteria, Sudbury, Mining, Metal, Blooms

\section{Introduction}

Many filamentous and colonial species are implicated with the production of potentially harmful water blooms (algal blooms, or cyanobacterial blooms) worldwide. Blooms are not defined in cell count, but generally describe phytoplankton biomasses much higher than normal in waterways, usually sufficient to producing a noticeable change [1] in the water color and create turbidity. Blooms may form on the water's surface or within the water column, creating a milky-green appearance. Under low turbulence, hypertrophic or eutrophic conditions

${ }^{*}$ Corresponding author.

How to cite this paper: Evans, S. and Saleh, M. (2015) Cyanobacteria Diversity in Blooms from the Greater Sudbury Area. Journal of Water Resource and Protection, 7, 871-882. http://dx.doi.org/10.4236/jwarp.2015.711071 
and high irradiance [2], cyanobacteria exceed other aquatic organisms (including proper algae) for nutrients and are able to multiply and increase the mass and density of aerotopes [3], thus causing them to float and form surface water blooms. The onset of blooms is often dependent on several nutrient levels, including the concentration of dissolved carbon, phosphorus and nitrogen (in organic forms including nitrate and ammonium) [4]-[6] as well as sulfur in some cases [7]. The organization of the bloom depends on the species present with some species able to control buoyancy using gas vesicles (aerotopes) allowing cells to move throughout the water strata [8]-[12]. Genera commonly involved in bloom formation include Microcystis, Anabaena, Aphanizomenon, and Oscillatoria [13]. Although cyanobacterial blooms may form rapidly (over the course of only a few days in some conditions), their senescence is dependent on various environmental factors including light intensity, water temperature [14], wind speed, and precipitation rates. Because cyanobacteria grow in all strata of watersheds, blooms that may have begun deteriorating may be simultaneously replaced by new cells, causing what appears to be a continuous bloom, lasting up to several months [15]. Though persistent blooms do occur, this mechanism is also involved in many cases. Water blooms are often located close to shore, and in some cases have been associated with large quantities of fertilizer used by those with shore-line property.

In addition to the unsightly nature of cyanobacterial blooms, many species contributing to blooms are also toxin-producing. Microcystin, a cyclic heptapeptide with hepatotoxic effects, is produced by Microcystis, Anabaena, Planktothrix, Nostoc, and Anabaenopsis species [13]. Other toxins produced include nodularin, cylindrospermopsin, saxitoxin, the anatoxin group of toxins and Lyngbya toxin-A [13]. Although these toxins are present in blooms, the mechanism of their production is not fully understood. Because these toxins are capable of causing severe injury to humans and animals that ingest contaminated water, it is of extreme interest to develop expedient methods for testing of both cyanobacteria and cyanotoxins to ensure that water supplies are not contaminated.

This study investigates the cyanobacterial populations present in several waterways in the Sudbury area as well as from a region of heavy farming. Identification by traditional morphological methods as well as by $16 \mathrm{~s}$ rRNA sequencing will be included, though morphological methods may allow for more comparable study. This research represents the introductory phase in a series of several studies, anticipated to distinguish cyanobacteria to the species level, and to create a more expedient testing method that could be employed to ensure public-water safety. Cyanobacteria are exceedingly important in watershed ecosystems, and because of the intense study of other aquatic organisms in Sudbury, cyanobacteria are a promising candidate for future investigations of watershed health. Several genera are likely to be found in the water-bloom samples, including toxin-producing genera, which have been found in previous testing by Environment Canada [16]. The species discovered from Sudbury samples, however, may be quite distinct from those found in other locations, due to the heavy metal and acid contamination throughout Sudbury area waterways.

\section{Materials and Methods}

\subsection{Study Sites}

\subsubsection{Sudbury}

Ontario $\left(46^{\circ} 29^{\prime} 24^{\prime \prime} \mathrm{N}, 81^{\circ} 0^{\prime} 36^{\prime \prime} \mathrm{W}\right)$, is the site of ongoing and past mining of metals (mostly Nickel), and thus presents a unique set of conditions for the growth of cyanobacteria. Sudbury area soils and watersheds have seen the impact of both heavy mining activities as well as the rehabilitation efforts that have been in place since the 1970's [17]. Several lakes in this area are now surrounded by residential housing, so fertilizer and pesticide use may also affect cyanobacterial growth and diversity. The mining activity has also led to the acidification of several Sudbury area lakes to a $\mathrm{pH}$ of less than 6 [18], potentially allowing for more tolerant forms to survive while selecting against intolerant species, and potentially leading to the decline in cyanobacterial competitors. The rehabilitation efforts employed include the application of limestone-fertilizer combination to soils [19], neutralization of final effluent [17] as well as the use of lime in several lakes, but not in all affected areas [20]. Along with the history or mining and metal contamination, Sudbury weather conditions make cyanobacterial survival more challenging by including winter temperatures often below $-30^{\circ} \mathrm{C}$, summer temperatures often above $30^{\circ} \mathrm{C}$ and wind gusts in excess of $100 \mathrm{~km} / \mathrm{hr}$ in certain locations [16]. The Sudbury samples were taken from several watersheds including Silver Lake, Ramsey Lake, Bethel Lake, Richard Lake, St. Charles Lake, MacFarlane Lake, Long Lake as well as a stream from the Laurentian University campus, which draws its water from Nepahwin Lake, in close proximity to a Golf and Country Club (Figure 1(a)). These sites were chosen based on their history 


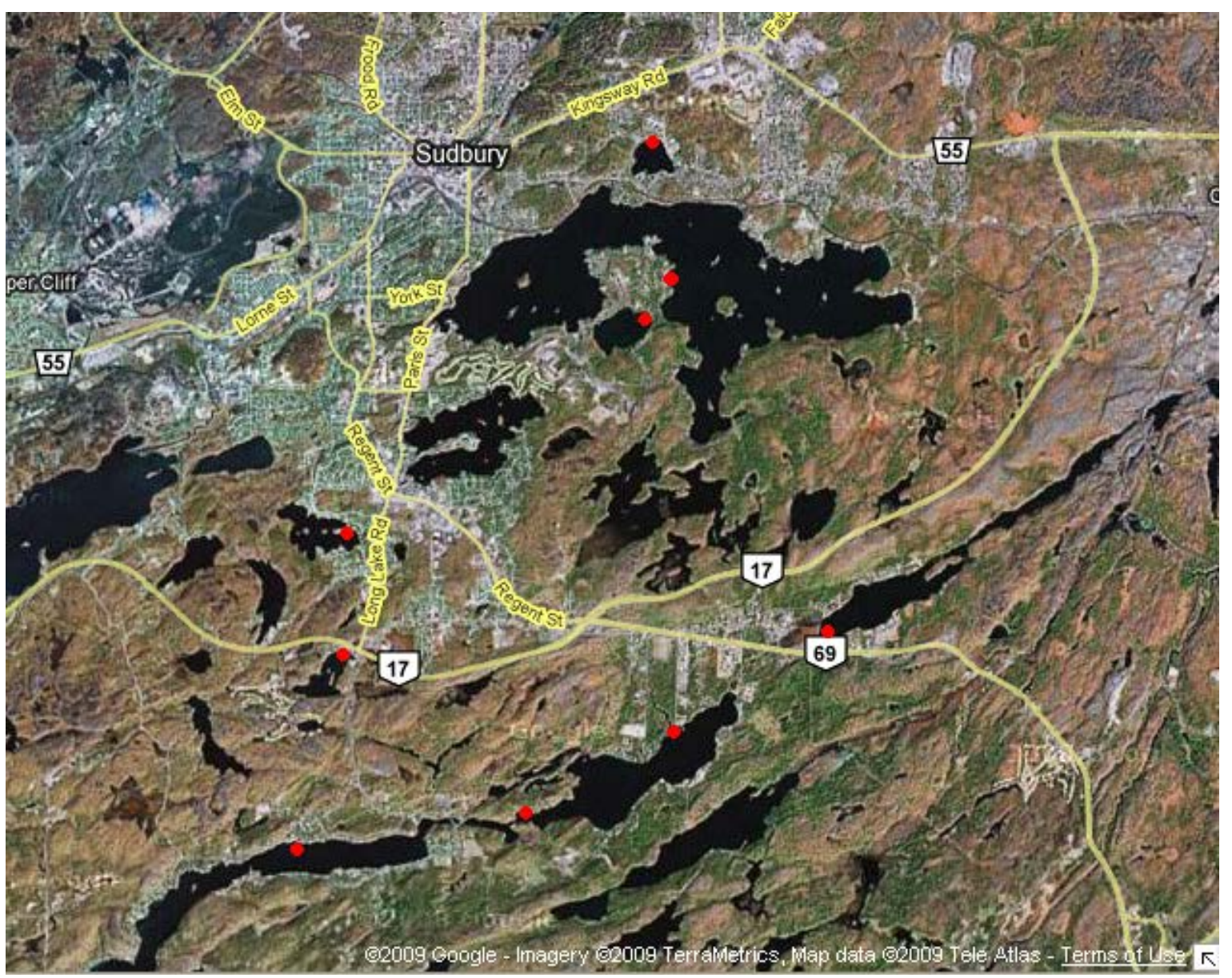

(a)

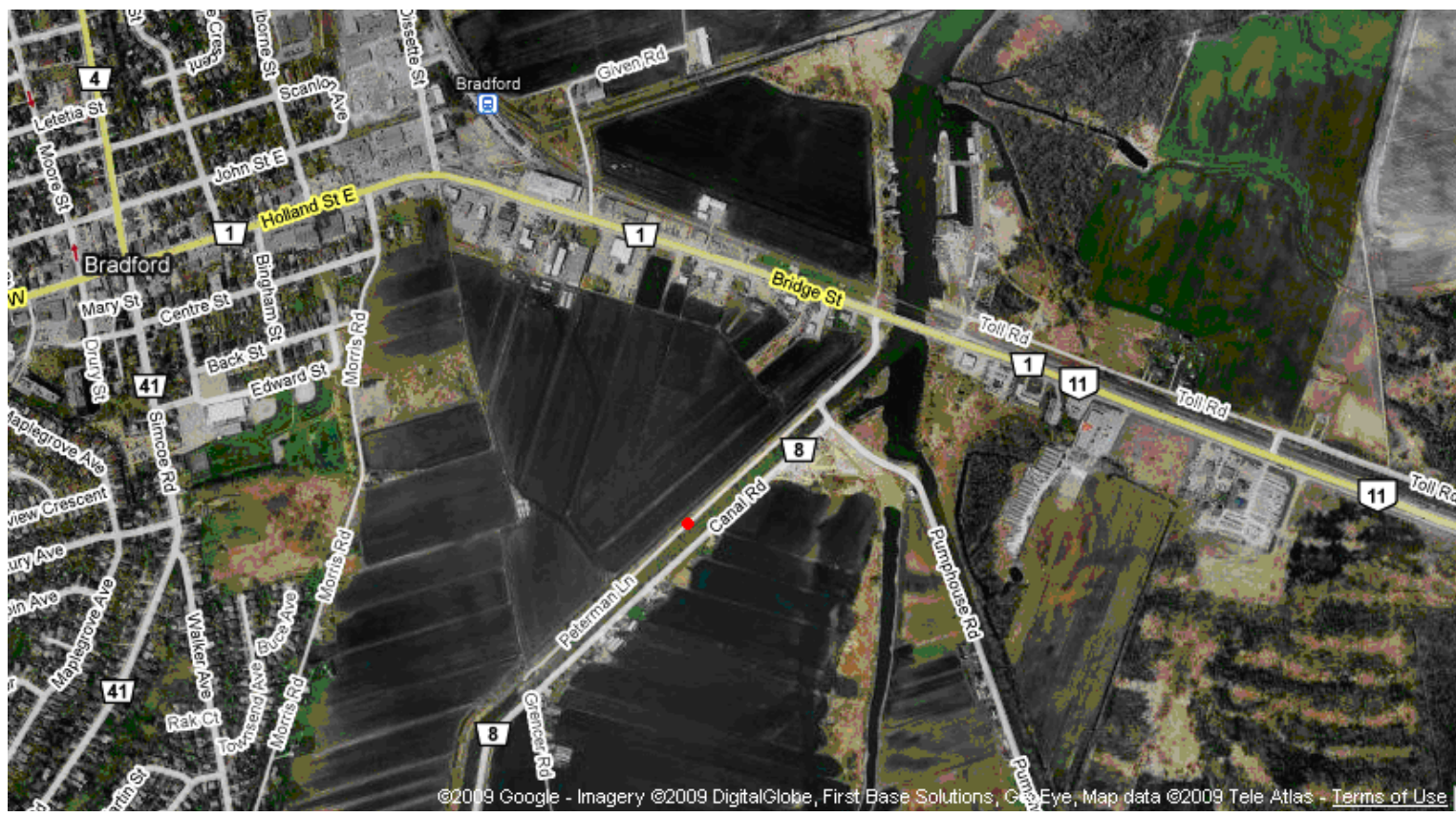

(b)

Figure 1. Study sites. (a) Sudbury, Ontario; (b) Bradford, Ontario. * Red dots signify collection sites. 
of bloom formation and the likelihood of the samples to contain viable cyanobacteria in the sample collection period, June to September. Samples were collected from the top 8 inches of water surface.

\subsubsection{Bradford}

Ontario $\left(44^{\circ} 7^{\prime} 0^{\prime \prime} \mathrm{N}, 79^{\circ} 34^{\prime} 0^{\prime \prime} \mathrm{W}\right)$, represents an area of intense agricultural farming including the Holland Marsh and much farmland in the surrounding region. Because of the extensive farming activity, the water supply in local streams, rivers and the canal network contains large quantities of fertilizers and pesticides. The Holland River concludes in Bradford, and is severed into two canals used almost exclusively as irrigation water supply for the agricultural fields located in the Holland marsh. Due to the proximity of the fields to the canal system, fertilizer undoubtedly contaminates canal water, and may even affect the southern-most portion of the Holland River. The site the "Canal" sample was taken from was $200 \mathrm{~m}$ from the base of the Holland River (downstream), from water parallel to Peterman Lane (Figure 1(b)). This location was chosen because it represents a region of water used to irrigate both northern and southern fields, where blooms are known to be the heaviest throughout the summer and early autumn. Although much interest has been generated by the contamination of the Holland River and this canal network, no significant morphological or genetic research has been undertaken in regards to the cyanobacteria present in this region, and the potential effects of the elevated fertilizer concentrations in the water.

\subsection{Sample Collection and Culturing}

The cyanobacterial bloom material was obtained in September 2008 from the shorelines of Silver Lake, Long Lake, Ramsey Lake, Minnow Lake, St. Charles Lake, Richard Lake, Bethel Lake, a stream on the Laurentian University campus and the Holland River canal-network. The Mac Farlane Lake sample was collected in November 2008, following confirmed reports of bloom formation. The collection involved sterile glassware to avoid any potential contamination due to leaching of plastic utensils, and collection of water surrounding the cell masses. The samples were washed with distilled water and added to $50 \mathrm{~mL}$ of a modified BG-11 media [21]. The BG-11 media was autoclaved in 1 liter batches at $121^{\circ} \mathrm{C}$ for 22 minutes, and $\mathrm{pH}$ adjusted (using $\mathrm{NaOH}$ and $\mathrm{HCl}$ ) to 7.5. Samples were also grown on 1\% BG-11 nutrient agar plates, using the same modified BG-11 media. Cycloheximide, at a concentration of $1 \mu \mathrm{L} / 1 \mathrm{~mL}$ modified BG-11, was added to liquid samples to ensure that only prokaryotic life would be sustained. All samples were cultured in glass test tubes under irradiance of a 23-Watt Blue Planet ${ }^{\mathrm{TM}}$ Spiral Soft White light bulb. The light-dark cycle was implemented to allow for 13 hours of irradiance, and 11 hours of darkness to ensure the photosynthetic and Calvin Cycle reactions were able to proceed, as they might in early and late summer. Samples were lightly shaken daily and were exposed to sterile air to ensure no bacterial contamination occurred due to the presence of other bacteria in the laboratory environment. After several months of cell culturing, some cells were separated and incubated in axenic conditions, in modified BG-11 media, in the same conditions as previously described. Modified versions of BG-11 (lacking $\mathrm{NaNO}_{3}$ ) were used in order to promote the fixation of atmospheric nitrogen in samples containing significant numbers of heterocytes, in samples lacking visible heterocytes, the modified BG-11 media used contained Na$\mathrm{NO}_{3}$.

\subsection{Microscopic Examination}

Blooms specimens were initially evaluated for level of contamination and for primary characterization of the mixed microorganism populations using standard light microscopy. The specimen was wet-mounted on a slide and observed at 400× and 1000× (Leica DM 300 microscope) following staining with methylene blue. Samples were also prepared using the Gram stain and the Toluidine Blue stain. Auto fluorescence of the specimen was visualized using a Hal 2000 fluorescence microscope.

\subsection{DNA Extraction from Axenic Cultures}

Field samples were processed within 24 hours to produce axenic cultures according to the method of Vaara et al. [22]. Cell cultures with cells visible and identifiable under light and fluorescence microscopy were used for the sequencing portion of this study. Approximately $1.0 \mathrm{~mL}$ of each sample, including some BG-11 media, were collected in $1.5 \mathrm{~mL}$ centrifugation tubes and sonicated using the Fisher Scientific FS20 Ultrasonic Cleaner (S/N 
RSA040604332, Pittsburgh PA) for 30 minutes. Samples were then centrifuged using at 12,000 $\times \mathrm{g}$ for 3 minutes, followed by removal of supernatant and resuspension with $200 \mu \mathrm{L}$ of $\mathrm{ddH}_{2} \mathrm{O}$. Centrifugation at 12,000 $\times \mathrm{g}$ for 2 minutes, removal of supernatant and resuspension in $100 \mu \mathrm{L}$ was performed, followed by another identical cycle using only $50 \mu \mathrm{L} \mathrm{ddH}_{2} \mathrm{O}$. Following centrifugation, five freeze-thaw cycles using liquid nitrogen and $65^{\circ} \mathrm{C}$ water were performed to ensure cellular disruption and release of DNA from the cells.

\subsection{PCR Amplification and Sequence Identification}

The forward primer CYA 106F (CGG ACG GGT GAG TAA CGC GTG A) and the reverse primer CYA 781R (GAC TAC TGG GGT ATC TAA TCC CAT T) were used for the PCR amplification of each sample [23]. The PCR protocol consisted of an initial denaturation step at $95^{\circ} \mathrm{C}$ for $5 \mathrm{~min}$, followed by 40 cycles at $94^{\circ} \mathrm{C}$ for $30 \mathrm{~s}$, $55^{\circ} \mathrm{C}$ for $30 \mathrm{~s}, 72^{\circ} \mathrm{C}$ for $60 \mathrm{~s}$, and a final single step at $72^{\circ} \mathrm{C}$ for 7 minutes. PCR products producing bands at 700 bp were purified using the Wizard DNA Purification System (Promega, Madison, WI). Samples of the purified PCR products and CYA 781R primer were sent to The Integrated DNA technologies-The Centre for Applied Genomics (at the Hospital for Sick Children, Toronto, ON). The sequences returned by the Centre for Applied Genomics were analyzed using the BLAST server against all known cyanobacterial sequences within the NCBI databases, with parameters constant for each sample. Sequence identifications were made based on BLAST scores and E values [24]. The S scores are cut-off scores optimized by the algorithm to maximize the maximal segment pair score (highest scoring pair of identical length segments chosen from 2 sequences). The higher the $\mathrm{S}$ score the more similar the 2 sequences are. The $\mathrm{E}$ value is related to the probability $\mathrm{P}$ that the identified sequence was randomly similarity [25]. For values less than 0.01 , the $\mathrm{E}$ and $\mathrm{P}$ values are equivalent. $\mathrm{E}$ is related to $\mathrm{P}$ as follows: $\mathrm{P}=1-\mathrm{e}^{-\mathrm{E}}$.

\section{Results and Discussion}

Algal blooms occur every year around the Greater Sudbury Area between the months of July and September; although blooms have been reported to occur as early as April and as late as November. This seems to be dependent on the variation in the seasons. In the Sudbury area, some years have a long winter season where the lakes are still mostly frozen at the surface in April. Some of the chemical properties of the lakes from which samples were identified are listed in Table 1 . The blooms are more often than not made up of mixed algae, diatoms, and cyanobacteria. Light microscopy determined the presence of cyanobacteria within a mixture of algae species (including Scenesdesmus sp.), diatoms (Asterionella sp., Tabellaria sp., and Fragilaria sp.), Bodo sp., and Taenia sp. ova, within the crude samples after collection (Figure 2). After the application of cycloheximide, algae and other eukaryotes were no longer present, and thus the growth was selective for cyanobacteria. The Gram stain technique was used to determine that all samples were Gram negative in accordance with literature [26], and the Toluidine Blue stain was used to differentially stain the nucleic acids within the cyanobacteria. The appearance of darker blue/purple regions in the cyanobacterial cells is indicative of the nucleoid region of the cells. The various genera present produced slightly varying arrangements of nucleotides, but all were concentrated in the central regions of the cells (Figure 3). Fluorescence microscopy was used to verify the presence of cyanobacteria in the samples by comparing sample fluorescence to that of CY5, producing magenta coloration in the presence of cyanobacteria (Figure 4). Akinetes, present in some samples, remained the most heavily

Table 1. Select chemical parameters of the lakes from which cyanobacteria were identified by rRNA sequencing (reproduced from Hutchinson, 2014).

\begin{tabular}{|c|c|c|c|c|c|}
\hline & \multicolumn{2}{|c|}{ Total phosphorus $(\mu \mathrm{g} / \mathrm{L})$} & \multirow{2}{*}{$\mathrm{Ni}(\mu \mathrm{g} / \mathrm{L})$} & \multirow{2}{*}{$\mathrm{Fe}(\mu \mathrm{g} / \mathrm{L})$} & \multirow{2}{*}{$\mathrm{Cu}(\mu \mathrm{g} / \mathrm{L})$} \\
\hline & Spring overturn & End of summer & & & \\
\hline Silver Lake & 6.1 & NA & 220 & 116 & 71 \\
\hline Richard Lake & 9.3 & NA & 63 & 32 & 8 \\
\hline MacFarlane Lake & 10.7 & 21.1 & 66 & 78 & 10 \\
\hline Long Lake & 7.2 & NA & 64 & 89 & 16 \\
\hline Lake Nepahwin & 10.8 & 75.9 & 74 & 53 & 15 \\
\hline
\end{tabular}




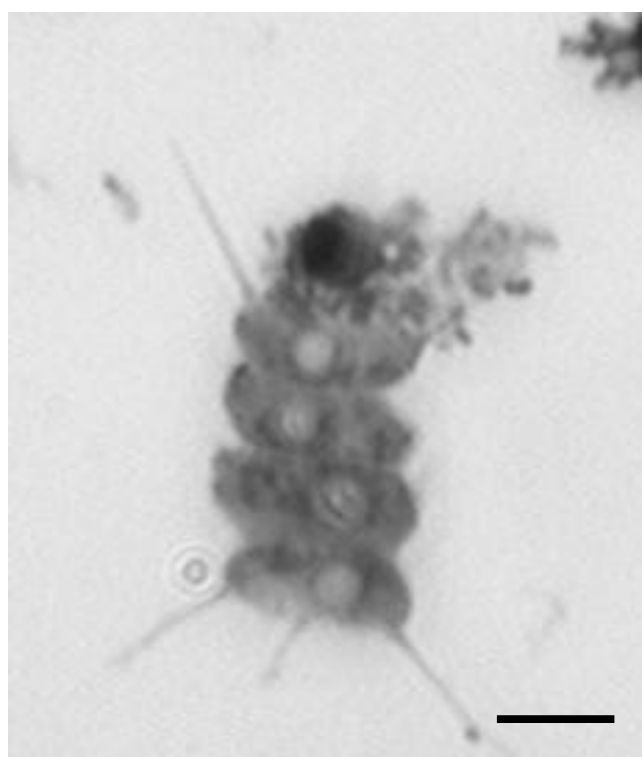

(a)

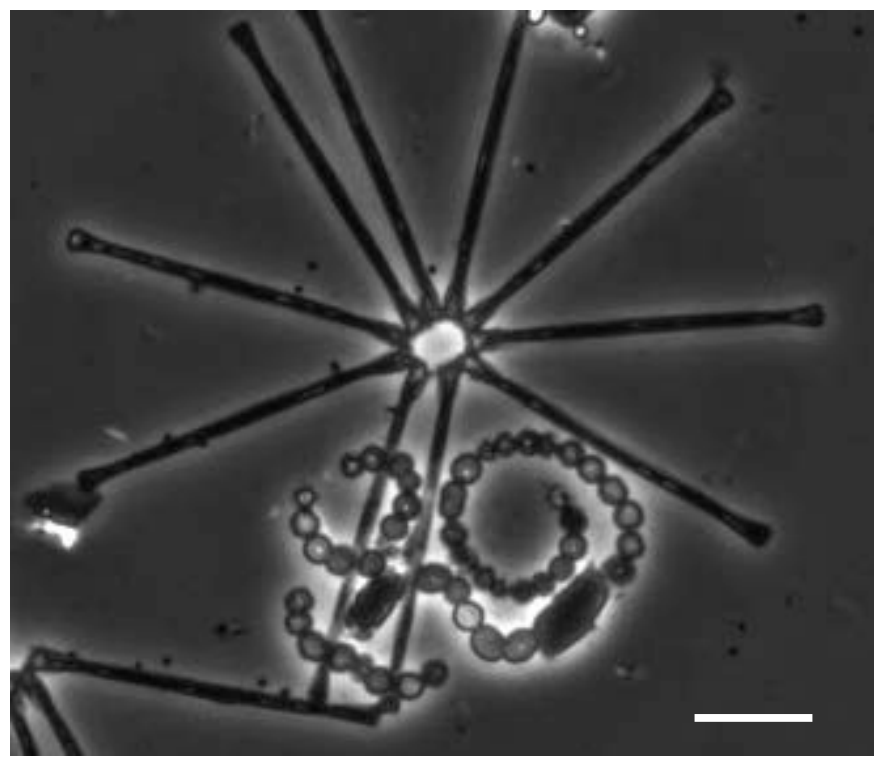

(b)

Figure 2. Collected crude sample images of other organisms present. (a) Bodo (toluidine blue stain); (b) Asterionella aggregating with Anabaena (fluorescence) (scale bar: $20 \mu \mathrm{m}$ ).

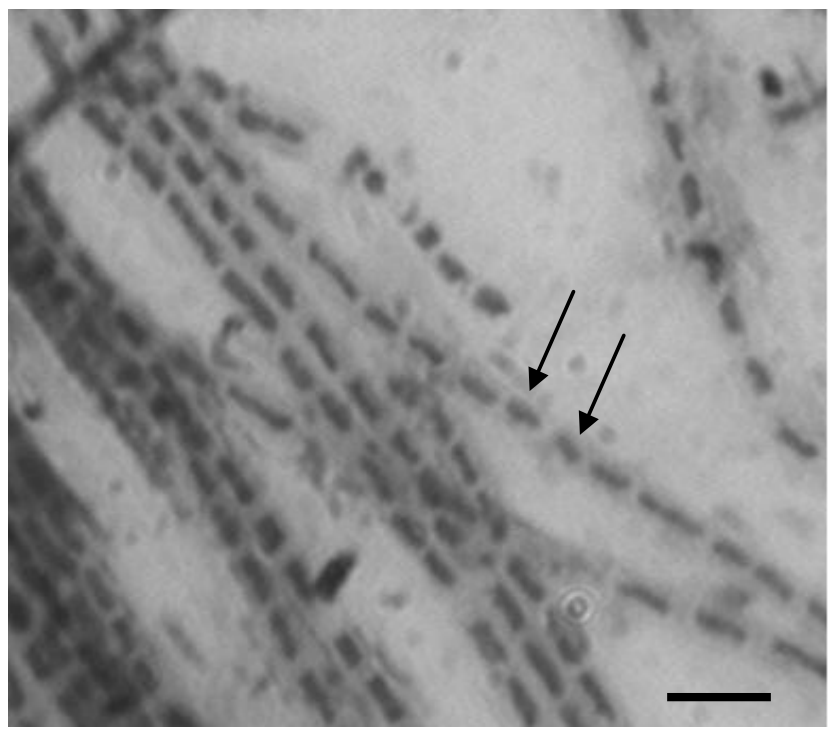

(a)

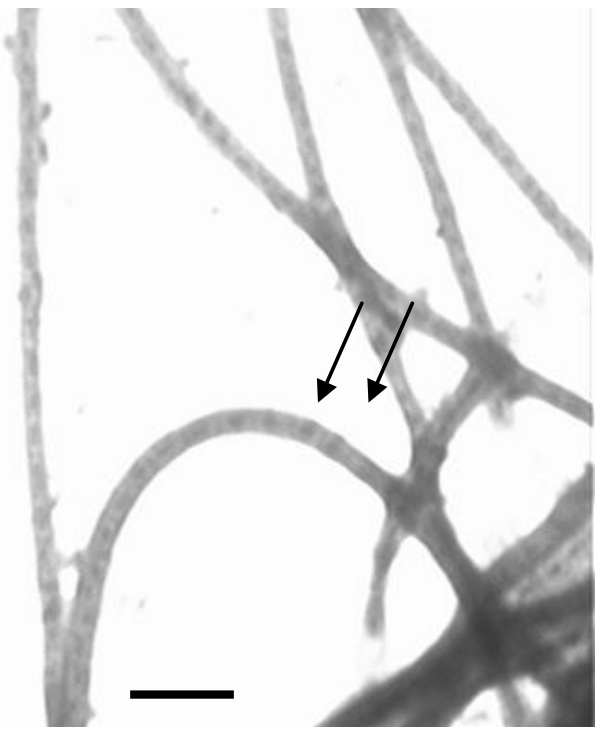

(b)

Figure 3. Toluidine blue staining of cyanobacterial samples. (a) and (b) Leptolyngbya. *Arrows indicate concentrated Toluidine blue dye (scale bar: $20 \mu \mathrm{m}$ ).

stained following de-staining, due to their storage of DNA [27] [28]. Polyphosphate granules also stain heavily; creating heavily stained cell centers. Using traditional morphological methods, several genera of cyanobacteria were found in the Sudbury lakes and Bradford canal samples. The mixed population observed with light microscopy is listed in Table 2. Figure 4 depicts light and fluorescent microscopy images of the samples. PCR amplification of axenic cultures yielded 6 workable amplification products, which were subjected to agarose gel electrophoresis, and viewed under UV irradiation to confirm the presence of a band at approximately $700 \mathrm{bp}$. The sequences of 5 samples (one of the six produced unusable sequence data) were obtained from the Integrated DNA technologies-The Centre for Applied Genomics (at the Hospital for Sick Children, Toronto, ON) following amplification and purification of the PCR products. Results of the BLAST search with these sequences are 


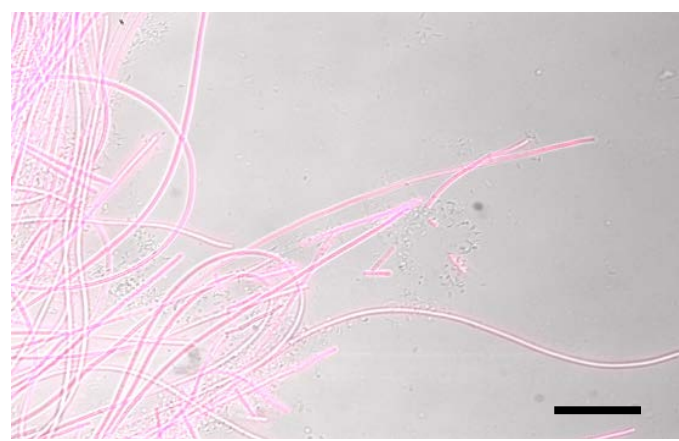

(a)

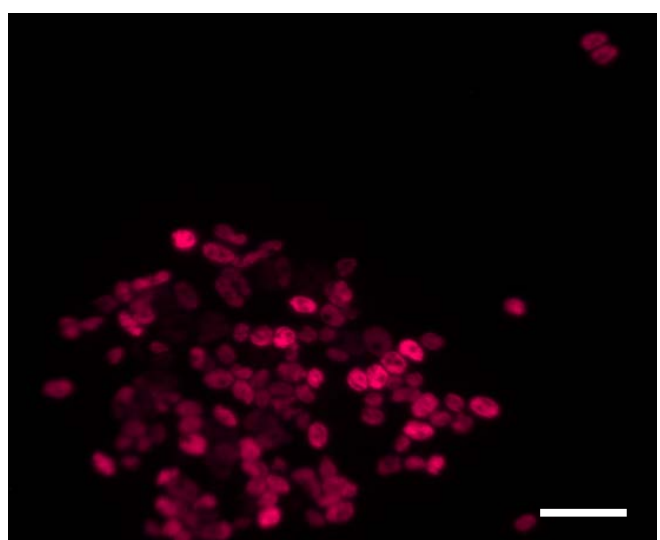

(c)

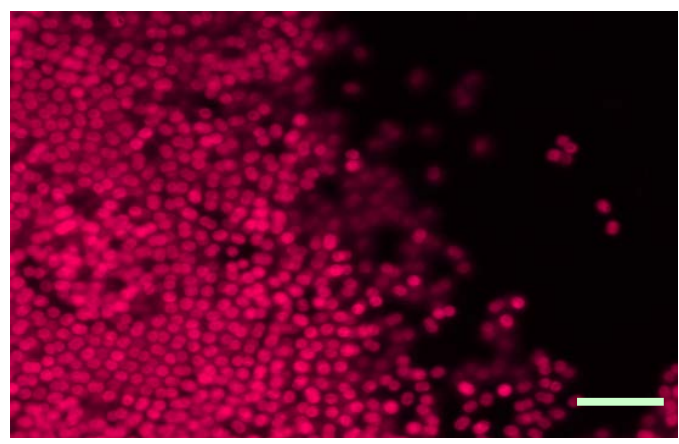

(e)

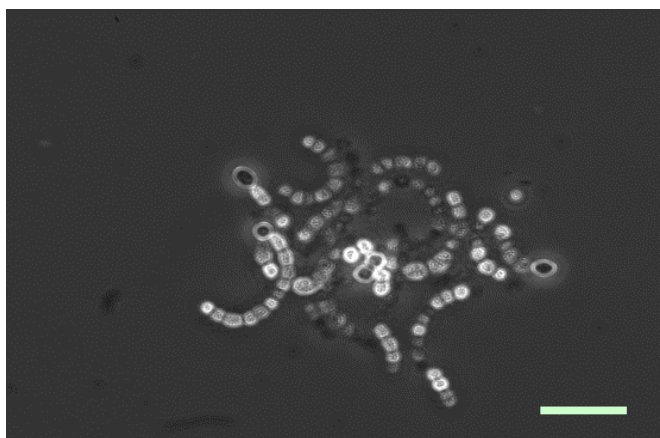

(g)

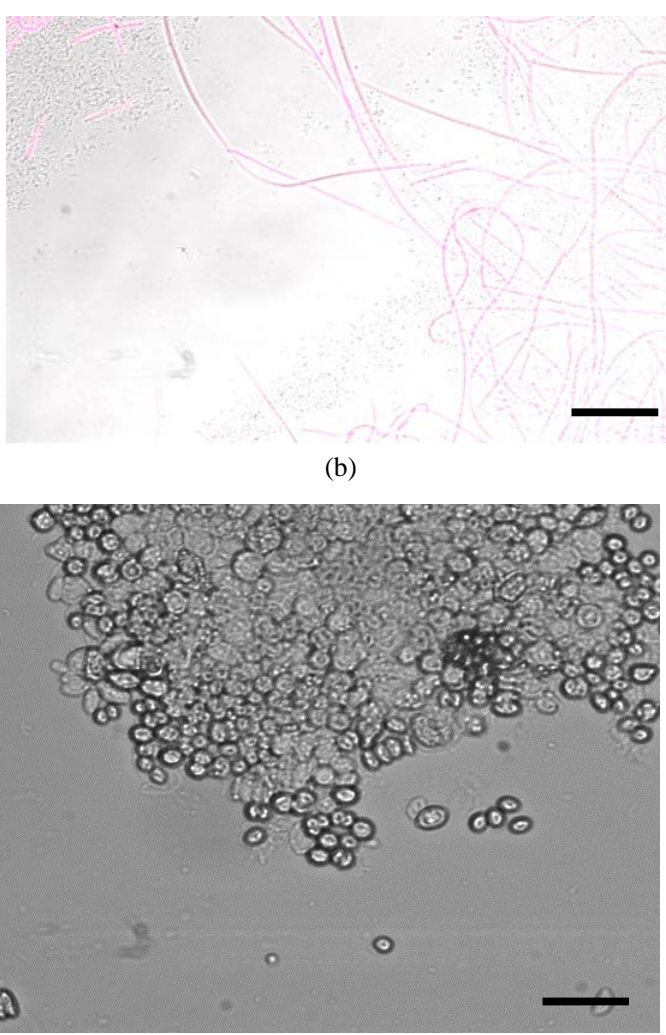

(d)

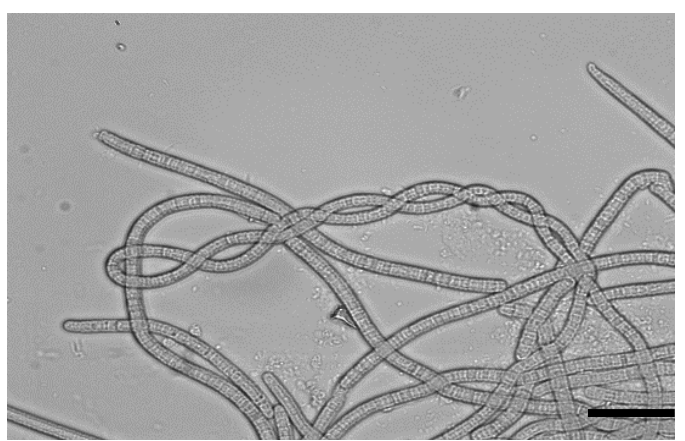

(f)

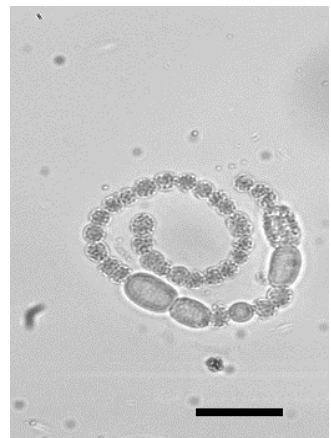

(h)

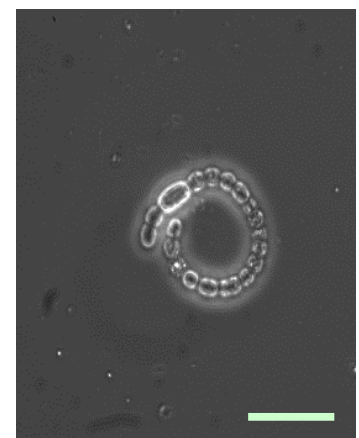

(i)

Figure 4. LM, BFM and FM images of sample cyanobacteria. (a) Leptolyngbya sp. (scale bar: $50 \mu \mathrm{m}$ ); (b) Leptolyngbya (scale bar: $50 \mu \mathrm{m}$ ); (c) Synechocystis (scale bar: $20 \mu \mathrm{m}$ ); (d) Mixed culture (scale bar: $20 \mu \mathrm{m}$ ); (e) Synechocystis (scale bar: $20 \mu \mathrm{m}$ ); (f) Oscillatoria (scale bar: $20 \mu \mathrm{m}$ ); (g) Cylindrospermosum (scale bar: 20 $\mu \mathrm{m})$; (h) Anabaena (scale bar: $20 \mu \mathrm{m}$ ); (i) Anabaena (scale bar: $20 \mu \mathrm{m}$ ). 
depicted in Table 3. Although many of the species returned as good "hits" by BLAST corresponded with the morphological analysis, many of the second and third sequences matches in the list were not even within the same family of cyanobacteria. This could be due to the primer mismatches produced using CYA 106F [29].

The cyanobacteria present in the samples were similar to those reported throughout Canada, North-Western Ontario and some prairie forms [30]. Cyanobacteria are found worldwide, including in the arctic and Antarctic [31]. Temperature is also a very important environmental factor in the growth of cyanobacteria, as each species (or genera) tends to have its own optimal growth temperature range, with their own extremes [32]. Although the optimal growth ranges of cyanobacteria normally center on $24^{\circ} \mathrm{C}$, the cyanobacteria found in Polar Regions have very broad ranges of growth tolerance, and thus can survive extremely cold seasonal temperatures [33]. Although the isolates of arctic, Antarctic and subarctic regions were not genetically adapted to low temperatures, they were tolerant to winter conditions because of the varying temperature range of the environment [33]. Northern Ontario cyanobacteria likely follow the same trend as these species, as the yearly temperature range is highly variable from below $-30^{\circ} \mathrm{C}$ to above $30^{\circ} \mathrm{C}$ [16]. The temperature range experienced by the Bradford samples was similar, with higher summer and winter temperatures $\left(35^{\circ} \mathrm{C}\right.$ and $-25^{\circ} \mathrm{C}$, respectively).

Cyanobacteria are typically acclimatized to specific (and sometimes narrow) ranges of irradiance, and increasing this irradiance can cause photo inhibition [1]. The effects of photo inhibition are difficult to assess in environmental samples of blooms, as the species present within blooms may impart protective qualities on one another; for instance the presence of carotenoids [34]. Although photo inhibition lowers the rate of photosynthesis, the exact effects depend on light intensity, exposure period [1], as well as accessibility to required nutrients. Production of axenic cultures in the laboratory was problematic most likely because it is difficult to replicate the natural light-nutrient requirements of those species in the laboratory. Light-nutrient requirements of cyanobacteria differ between species [35], so for optimal growth rates differential light intensities and exposure periods should be used. The spectral distribution of light may also play an effect, as significant variation in growth rates can be achieved using red, blue, green and white light [36].

The supply of phosphorus and nitrogen has a massive effect on the growth of cyanobacteria, and can be briefly explained using the Total Nitrogen:Total Phosphorus (TN:TP) ratio. Because many bloom-forming cyanobacteria

Table 2. Genera observed in viable lake samples.

\begin{tabular}{ccc}
\hline Sample Location & Sample Name & Genera Observed* $^{*}$ \\
Bradford Canal & $\mathrm{S} 2$ & Synechocystis \\
MacFarlane Lake & $\mathrm{S} 3, \mathrm{~S} 8$ & Leptolyngbya or \\
Nepahwin Lake & $\mathrm{S} 6$ & Anabaena, Nostoc, Borzia \\
Long Lake & $\mathrm{S} 12$ & Leptolyngbya, Phormidium \\
Richard Lake & $\mathrm{S} 13$ & Pseudoanabaena, Phormidium \\
Silver Lake & $\mathrm{S} 14$ & Oscillatoria, Planktothrix \\
\hline
\end{tabular}

${ }^{*}$ Using microscopic examination.

Table 3. Sample sequence BLAST results. All sequences were BLASTED against 16S rRNA sequences in the database.

\begin{tabular}{|c|c|c|c|c|c|c|c|}
\hline & Description & Total Score & \% Query Coverage & E Value & Max Ident. & Accession & Sequence length \\
\hline $\mathrm{S} 2$ & Synechocystis & 723 & $100 \%$ & 0 & $98 \%$ & gi|156446603|EU078508.1 & 582 bp \\
\hline S3 & Leptolyngbya & 667 & $100 \%$ & 0 & $91 \%$ & gi|82697091|AJ639895.1 & 582 bp \\
\hline \multirow{2}{*}{ S6* } & Anabaena & 746 & $99 \%$ & 0 & $97 \%$ & gi|154361749|EU022721.1 & \multirow{2}{*}{614 bp } \\
\hline & Trichormus variabilis & 746 & $99 \%$ & 0 & $97 \%$ & gi|78217345|DQ234833.1 & \\
\hline S7 & Synechocystis & 268 & $96 \%$ & $7 e-69$ & $90 \%$ & gi|189484788|EU729078.1 & 250 bp \\
\hline S8 & Leptolyngbya & 757 & $99 \%$ & 0 & $99 \%$ & gi|82697091|AJ639895.1 & 599 bp \\
\hline
\end{tabular}

*BLAST analysis produced two different results with the same match percentage. 
are $\mathrm{N}_{2}$-fixing (Anabaena, Aphanizomenon, Nodularia) [1], when the $\mathrm{N}: \mathrm{P}$ ratio declines, their ability to thrive exceeds the ability of other aquatic organisms, enabling them to reproduce and form massive blooms. Nitrogen plays a key role in the formation of gas vacuoles, and thus is critical for control of cell buoyancy [1]. Nitrogen metabolism in cyanobacteria is closely connected with carbon fixation, as both processes compete for reductants produced through photosynthesis, and when nitrogen levels decline, the nitrogen uptake capacity is increased requiring a new supply of reductants and carbons skeletons for creation of useful nitrogenous compounds [37] [38]. Nitrogen is stored in cyanobacteria within phycocyanin and cyanophycin, in cases of nitrogen starvation cells lose pigments because of the degradation of phycocyanin [39].

Polyphosphate granules within cyanobacterial cells offer phosphate stores. Under phosphorus-limited conditions the phosphorus uptake potential increases to allow for maximal capturing, while the cellular concentrations and phosphorus dependent growth rates decline, in order to store and conserve as much as possible [1]. Eutrophication, especially by phosphorus, often leads to shifts in phytoplankton composition towards bloom-forming types of cyanobacteria [12] [40] [41]. Studies performed on several oligotrophic Canadian lakes showed that when the TN:TP ratio was high (14:1), algal species dominated, while when the TN:TP decreased to 5:1 nitrogen-fixing cyanobacteria dominated [42] [43]. This also shows the immense role of phosphorus, as at higher relative concentrations (thus lower TN:TP ratios), cyanobacteria growth increases.

Metal stress can cause grave effects on cyanobacteria. Metal contaminants (zinc, copper, etc.) and the use of fertilizers and detergents containing phosphorus has been found to cause cumulative effects on cyanobacteria by inhibiting growth; although the presence of calcium and phosphate in the presence of metals has also been found to reduce their toxicity to cyanobacteria [44] [45]. Morphological effects of elevated copper include the production of sub-spherical rather than coccoid Synechococcus PCC 6301 [45] as well as the inhibition of photosynthesis in Nostoc calcicola [46]. Polyphosphate granules are involved in the sequestration of metals; therefore they are more abundant in cells stressed by zinc or copper-triads [47]. Strains collected from metal-polluted areas have shown tolerance to elevated levels of metals in subsequent axenic culture [45] [48].

Metallothioneins (MTs) bind to and sequester metals of the zinc and copper triads [49] so the determination of metallothionein-coding and transporter-coding genes could provide insight into the processes used by the Sudbury cyanobacteria to survive in the metal rich waters. Several metallothioneins and transporters have been characterized in other cyanobacterial strains and those in Sudbury samples are likely similar in function. Nickel and aluminum, also found at elevated levels in many Sudbury lakes; do not appear to have any functional role in cyanobacteria, and aluminum has been reported to accumulate in and immobilize polyphosphate granules, eventually leading to phosphorus starvation in the cell [50].

\section{Conclusions}

Morphological examination of several samples from five lakes in The Greater Sudbury Area in near Northern Ontario showed the presence of Synechocystis, Leptolyngbya, Anabaena, Cylindrospermum, Nostoc, Borzia, Phormidium, Pseudoanabaena, Oscillatoria, and Planktothrix.

Axenic cultures of five isolates were generated and their identities were confirmed by sequencing of the $16 \mathrm{~S}$ rRNA as Synechocystis (samples S2 and S7), Leptolyngbya (samples S3 and S8), and Anabaena (sample S6). Various species of Anabaena and Planktothrix are capable of producing toxins, but the isolates in this study were not screened for toxin production.

\section{Acknowledgements}

This work was supported by funds from a Louise Picard Public Health grant to MS and a Laurentian University Research Fund grant to MS.

\section{References}

[1] Oliver, R.L. and Ganf, G.G. (2000) Freshwater Cyanobacteria. In: Whitton, B.A. and Potts, M., Eds., The Ecology of Cyanobacteria: Their Diversity in Time and Space, Kluwer, Boston, 149-187.

[2] Zohary, T. and Breen, C.M. (1989) Environmental Factors Favoring the Formation of Microcystis aeruginosa Hyperscums in a Hypertrophic Lake. Hydrobiology, 178, 179-192. http://dx.doi.org/10.1007/BF00006025

[3] Walsby, A.E. (1994) Gas Vesicles. Microbiological Review, 58, 94-144. 
[4] Merel, S., Walker, D., Chicana, R., Snyder, S., Baures, E. and Thomas, O. (2013) State of Knowledge and Concerns on Cyanobacterial Blooms and Cyanotoxins. Environment International, 59, 303-327. http://dx.doi.org/10.1016/j.envint.2013.06.013

[5] Kaebernick, M., Neilan, B.A., Börner, T. and Dittmann, E. (2000) Light and the Transcriptional Response of the Microcystin Biosynthesis Gene Cluster. Applied and Environmental Microbiology, 66, 3387-3392. http://dx.doi.org/10.1128/AEM.66.8.3387-3392.2000

[6] Vezie, C., Brient, L., Sivonen, K., Bertru, B., Lefeuvre, J.-C. and Salkinoja-Salonen, M. (1997) Variation of Microcystin Content of Cyanobacterial Blooms and Isolated Strains in Lake Grand-Lieu (France). Microbial Ecology, 35, 126-135. http://dx.doi.org/10.1007/s002489900067

[7] Thiel, T., Bramble, J. and Rogers, S. (1989) Optimum Conditions for Growth of Cyanobacteria on Solid Media. FEMS Microbiology Letters, 61, 27-32. http://dx.doi.org/10.1111/j.1574-6968.1989.tb03546.x

[8] Reynolds, C.S. and Walsby, A.E. (1975) Water-Blooms. Biological Reviews, 50, 437-481. http://dx.doi.org/10.1111/j.1469-185X.1975.tb01060.x

[9] Ganf, G.G. and Oliver, R.L. (1982) Vertical Separation of Light and Available Nutrients as a Factor Causing Replacement of Green Algae by Blue-Green Algae in the Plankton of a Stratified Lake. Journal of Ecology, 70, 829-844. http://dx.doi.org/10.2307/2260107

[10] Van Rijn, J. and Shilo, M. (1985) Carbohydrate Fluctuations, Gas Vacuolation, and Verticalmigration of Scum-Forming Cyanobacteria in Fishponds. Limnology and Oceanography, 30, 1219-1228. http://dx.doi.org/10.4319/10.1985.30.6.1219

[11] Walsby, A.E. (1987) Mechanisms of Buoyancy Regulation by Planktonic Cyanobacteria with Gas Vesicles. In: Fay, P. and Van Baalen, C., Eds., The Cyanobacteria: A Comprehensive Review, Elsevier, Amsterdam, 376-392.

[12] Reynolds, C.S., Oliver, R.L. and Walsby, A.E. (1987) Cyanobacterial Dominance: The Role of Buoyancy Regulation in Dynamic Lake Environments. New Zealand Journal of Marine and Freshwater Research, 21, 379-390. http://dx.doi.org/10.1080/00288330.1987.9516234

[13] Burns, B.P., Saker, M.L., Moffitt, M.C. and Neilan, B.A. (2005) Molecular Detection of Genes Responsible for Cyanobacterial Toxin Production in the Genera Microcystis, Nodularia, and Cylindrospermopsin. In: Spencer, J.F.T. and Ragout de Spencer, A.L., Eds., Methods in Molecular Biology, Vol. 268: Public Health Microbiology: Methods and Protocols, Humana Press, Totowa, 213-222.

[14] Pietsch, C., Wiegand, C., Ame, M.V., Nucklisch, A., Wunderlin, D. and Pflugmacher, S. (2001) The Effects of a Cyanobacterial Crude Extract on Different Aquatic Organisms: Evidence for Cyanobacterial Toxin Modulating Factors. Environmental Toxicology, 16, 535-524. http://dx.doi.org/10.1002/tox.10014

[15] Kromkamp, J. and Walsby, A.E. (1990) A Computer Model of Buoyancy and Vertical Migration in Cyanobacteria. Journal of Plankton Research, 12, 161-183. http://dx.doi.org/10.1093/plankt/12.1.161

[16] Canadian Daily Climate Data (2009) National Climate Data and Information Archive. Environment Canada, Ottawa. http://www.climate.weatheroffice.ec.gc.ca/climateData/canada_e.html

[17] Heale, E.L. (1995) Integrated Management and Progressive Rehabilitation of Industrial Lands. In: Gunn, J.M., Ed., Restoration and Recovery of an Industrial Region, Springer, Berlin, 289-298.

[18] Conroy, N.I. Hawley, K. and Keller, W. (1978) Extensive Monitoring of Lakes in the Greater Sudbury Area, 19741976. Ontario Ministry of the Environment, Sudbury, 40.

[19] Nriagu, J.O., Wong, H.K.T., Lawson, G. and Daniel, P. (1998) Saturation of Ecosystems with Toxic Metals in Sudbury basin, Ontario, Canada. The Science of the Total Environment, 223, 99-117. http://dx.doi.org/10.1016/S0048-9697(98)00284-8

[20] Winterhalder, K. (1996) Environmental Degradation and Rehabilitation of the landscape around Sudbury, a Major Mining and Smelting Area. Environmental Reviews, 4, 185-224. http://dx.doi.org/10.1139/a96-011

[21] Rippka, R., Deruelles, J., Waterbury, J., Herdman, M. and Stanier, R. (1979) Generic Assignments, Strain Histories and Properties of Pure Cultures of Cyanobacteria. Journal of General Microbiology, 111, 1-61. http://dx.doi.org/10.1099/00221287-111-1-1

[22] Vaara, T., Vaara, M. and Niemelä, S. (1979) Two Improved Methods for Obtaining Axenic Cultures of Cyanobacteria. Applied and Environmental Microbiology, 38, 1011-1014.

[23] Brosius, J., Dull, T., Sleeter, D.D. and Noller, H.F. (1981) Gene Organization and Primary Structure of a Ribosomal RNA Operon from Escherichia coli. Journal of Molecular Biology, 148, 107-127. http://dx.doi.org/10.1016/0022-2836(81)90508-8

[24] Altschul, S.F., Gish, W., Miller, W., Myers, E.W. and Lipman, D.J. (1990) Basic Local Alignment Search Tool. Journal of Molecular Biology, 215, 403-410. http://dx.doi.org/10.1016/S0022-2836(05)80360-2 
[25] Altschul, S.F. and Erickson, B.W. (1985) Significance of Nucleotide Sequence Alignments: A Method for Random Sequence Permutation that Preserves Dinucleotide and Codon Usage. Molecular Biology and Evolution, 2, 526-538.

[26] Stanier, R.Y. and Cohen-Bazire, G. (1977) Phototrophic Prokaryotes: The Cyanobacteria. Annual Reviews in Microbiology, 31, 225-274. http://dx.doi.org/10.1146/annurev.mi.31.100177.001301

[27] Sutherland, J.M., Reaston, J., Stewart, W.D.P. and Herdman, M. (1985) Akinetes of the Cyanobacterium Nostoc PCC 7524: Macromolecular Composition, Structure and control of Differentiation. Journal of General Microbiology, 131, 2855-2863.

[28] Sutherland, J.M., Stewart, W.D.P. and Herdman, M. (1985) Akinetes of the Cyanobacterium Nostoc PCC 7524: Morphological Changes during Synchronous Germination. Archives of Microbiology, 142, 269-274. http://dx.doi.org/10.1007/BF00693402

[29] Nubel, U., Engelen, B., Felske, A., Snaidr, J., Wieshuber, A., Amann, R.I., Ludwig, W. and Backhaus, H. (1996) Sequence Heterogeneities of Genes Encoding16S rRNAs in Paenibacillus polymyxa Detected by Temperature Gradientgel Electrophoresis. Journal of Bacteriology, 178, 5636-5643.

[30] Vincent, W.F. (2009) Cyanobacteria. Encyclopedia of Inland Waters, 3, 226-232.

[31] Zakhia, F., Jungblut, A.D., Taton, A., Vincent, W.F. and Wilmotte, A. (2008) Cyanobacteria in Cold Ecosystems. In: Margesin, R., Schinner, F., Marx, J.-C. and Gerday, C., Eds., Psychrophiles: From Biodiversity to Biotechnology, Springer, Heidelberg, 121-135. http://dx.doi.org/10.1007/978-3-540-74335-4_8

[32] Ward, D.M. and Castenholz, R.W. (2000) Cyanobacteria in Geothermal Habitats. In: Whitton, B.A. and Potts, M., Eds., The Ecology of Cyanobacteria: Their Diversity in Time and Space, Kluwer, Boston, 37-59

[33] Tang, E.P.Y., Tremblay, R. and Vincent, W.F. (1997) Cyanobacterial Dominance of Polar Freshwater Ecosystems: Are High-Latitude Mat-Formers Adapted to Low Temperature? Journal of Phycology, 33, 171-181. http://dx.doi.org/10.1111/j.0022-3646.1997.00171.x

[34] Paerl, H.W. (1983) Partitioning of $\mathrm{CO}_{2}$ Fixation in the Colonial Cyanobacterium Microcystis Aeruginosa: Mechanism Promoting Formation of Surface Scums. Applied and Environmental Microbiology, 46, 252-259.

[35] Foy, R.H., Gibson, C.E. and Smith, R.V. (1976) The Influence of Day Length, Light Intensity and Temperature on the Growth Rates of Planktonic Blue-Green Algae. British Phycological Journal, 11, 151-163. http://dx.doi.org/10.1080/00071617600650181

[36] Wyman, M. and Fay, P. (1986) Underwater Light Climate and the Growth and Pigmentation of Planktonic Blue-Green Algae (Cyanobacteria) I. The Influence of Light Quality. Proceedings of the Royal Society Series B, 277, 367-380. http://dx.doi.org/10.1098/rspb.1986.0027

[37] Guerrero, M.G. and Lara, C. (1987). Assimilation of Inorganic Nitrogen. In: Fay, P. and van Baalen, C., Eds., The Cyanobacteria, Elsevier, Amsterdam, 163-186.

[38] Turpin, D.H. (1991) Effects of Inorganic N Availability on Algal Photosynthesis and Carbon Metabolism. Journal of Phycology, 27, 14-20. http://dx.doi.org/10.1111/j.0022-3646.1991.00014.x

[39] Tandeau de Marsec, N. and Houmard, J. (1993) Adaptation of Cyanobacteria to Environmental Stimuli: New Steps towards Molecular Mechanisms. FEMS Microbiology Reviews, 104, 119-190. http://dx.doi.org/10.1111/j.1574-6968.1993.tb05866.x

[40] Steinberg, C.E.W. and Hartman, M. (1988) Planktonic Bloom-Forming Cyanobacteria and the Eutrophication of Lakes and Rivers. Freshwater Biology, 20, 279-287. http://dx.doi.org/10.1111/j.1365-2427.1988.tb00452.x

[41] Steinberg, C.E.W. and Gruhl, E. (1992) Physical Measures to Inhibit Planktonic Cyanobacteria. In: Sutcliffe, D.W. and Jones, J.G., Eds., Eutrophication: Research and Application to Water Supply, Freshwater Biological Association, Cumbria, 163-184.

[42] Schindler, D.W. (1977) Evolution of Phosphorus Limitation in Lakes. Science, 195, 260-262. http://dx.doi.org/10.1126/science.195.4275.260

[43] Stockner, J.G. and Shortreed, K.S. (1988) Response of Anabaena and Synechococcus Tomanipulation of Nitrogen:Phosphorus Ratios in a Lake Fertilization Experiment. Limnology and Oceanography, 33, 1348-1361.

[44] Say, P.J. and Whitton, B.A. (1977) Influence of Zinc on Lotic Plants. II. Environmental Effects on Toxicity of Zinc to Hormidium rivulare. Freshwater Biology, 7, 377-384. http://dx.doi.org/10.1111/j.1365-2427.1977.tb01685.x

[45] Shehata, F.H.A. and Whitton, B.A. (1982) Zinc Tolerance in Strains of the Blue-Green Alga Anacystis nidulans. British Phycological Journal, 17, 5-12. http://dx.doi.org/10.1080/00071618200650021

[46] Verma, S.K. and Singh, H.N. (1991) Evidence for Energy-Dependent Copper Efflux as Amechanism of Cu ${ }^{2+}$ Resis- $^{-}$ tance in the Cyanobacterium Nostoc calcicola. FEMS Microbiology Letters, 84, 291-294.

http://dx.doi.org/10.1111/j.1574-6968.1991.tb04612.x 
[47] Jensen, T.E., Baxter, M., Rachlin, J.W. and Jani, V. (1982) Uptake of Heavy Metals by Plectonema boryanum (Cyanophyceae) into Cellular Components, Especially Polyphosphate Bodies: An X-Ray Energy Dispersive Study. Environmental Pollution Series A, Ecological and Biological, 27, 119-127. http://dx.doi.org/10.1016/0143-1471(82)90104-0

[48] Takamura, N., Kasai, F. and Watanabe, M.M. (1989) Effects of Cu, Cd and Zn on Photosynthesis of Freshwater Benthic Algae. Journal of Applied Phycology, 1, 39-52. http://dx.doi.org/10.1007/BF00003534

[49] Kaegi, J.H.R. and Schaeffer. A. (1988) Biochemistry of Metallothionein. Biochemistry, 27, 8509-8515. http://dx.doi.org/10.1021/bi00423a001

[50] Pettersson, A., Hallbom, L. and Bergman, B. (1988) Aluminum Effects on Uptake and Metabolism of Phosphorus by the Cyanobacterium Anabaena cylindrica. Plant Physiology, 86, 112-116. http://dx.doi.org/10.1104/pp.86.1.112 